\title{
Carthamus species in the ancient Near East and south-eastern Europe: archaeobotanical evidence for their distribution and use as a source of oil
}

\author{
Elena Marinova $\cdot$ Simone Riehl
}

Received: 1 August 2008/Accepted: 17 December 2008/Published online: 29 January 2009

(C) Springer-Verlag 2009

\begin{abstract}
We present an overview of archaeobotanical Carthamus spp. finds from Neolithic to medieval sites in the Near East and adjacent areas. A particular focus is put on the cultivated form of the genus. Safflower appears first in a number of early Bronze Age (3000 B.c.) sites in northern and central Syria. From there it apparently spread to Egypt, the Aegean and south-eastern Europe. The Near Eastern Bronze Age evidence shows a striking exclusiveness in the distribution patterns of safflower and flax, with flax being restricted to Levantine and Iranian sites. This may reflect the contrasting ecological requirements of the two crops, with safflower being well adapted to drought and salinity and thus to arid conditions. At the same time the geographically complementary evidence may indicate a similar use of the two crops and most probably suggests
\end{abstract}

Communicated by M. van der Veen.

Electronic supplementary material The online version of this article (doi:10.1007/s00334-009-0212-z) contains supplementary material, which is available to authorized users.

\section{E. Marinova}

Department of Botany, Sofia University,

"Sv. Kliment Ohridsky", Sofia, Bulgaria

Present Address:

E. Marinova $(\square)$

Center for Archaeological Sciences,

Katholieke Universiteit Leuven, Celestijnenlaan 200E,

3001 Leuven, Belgium

e-mail: elena.marinova@bio.kuleuven.be

\section{S. Riehl}

Institute of Prehistory and Quaternary Ecology,

Archaeological Sciences (ZNA), Tübingen University,

Burgsteige 11, 72070 Tübingen, Germany

e-mail: simone.riehl@uni-tuebingen.de that the safflower was also used for oil almost from the beginning of its cultivation.

Keywords Bronze age $\cdot$ Near East $\cdot$ Eastern Mediterranean · Eastern Europe - Oil crop · Dye plant

\section{Introduction}

The genus Carthamus is found mainly in arid and semi-arid environments and is reported to be highly tolerant to drought stress (Quiroga et al. 2001). Its cultivated representative C. tinctorius L. (safflower) is a crop of minor economic importance today (see faostat.fao.org/default.aspx), with different varieties mainly used for oil or dye production (Knowles and Ashri 1995). Recent genetic studies (Chapman and Bruke 2007) suggest that $C$. palaestinus, a wild species restricted to the deserts of southern Israel and western Iraq (Zeven and Zhukovsky 1975), is the progenitor of C. tinctorius. However, according to the "Euro \& Med Plantbase," an up-to-date internet database for European and Mediterranean plant diversity, C. palaestinus is an invalid species name for $C$. persicus Willd. The latter has a wide distribution (including Turkey, Syria, and the Levant) that was previously considered the Mesopotamian sub-region of the Irano-Turanian floristic region (http://ww2.bgbm.org/ EuroPlusMed/query.asp; Hanelt 1961). Knowles and Ashri (1995) suggested that safflower was first cultivated in this area, and Weiss (2000) further specified the area of cultivation as being in central Syria, near the river Euphrates. With reference to Hanelt (1961) and Kupcov (1932), it seems likely that the use of the cultivated crop was preceded by the use of the wild species $C$. persicus in the Mesopotamian subregion, and $C$. oxyacanthus in the central sub-region of the Irano-Turanian floristic region, including northwest India. 
With respect to archaeobotanical data published before 2004, as for example available in the Archaeobotanical database of Near Eastern and Eastern Mediterranean sites (Riehl and Kümmel 2005), the archaeobotanical information can be used to track changes in the use of a given plant by revealing its distribution over time and space. Archaeobotany provides direct evidence for the ancient distribution and use of Carthamus spp.

Thus the aim of this paper is to answer the question of how the distribution of archaeobotanical Carthamus finds can reveal its ancient use, with a main focus on the cultivated species $C$. tinctorius. In order to develop a more extensive picture, the Neolithic and Chalcolithic finds of the genus Carthamus are also considered. Furthermore, the paper explores the relation of the dispersal of $C$. tinctorius to cultural developments in eastern Europe.

\section{Materials and methods}

Morphology and identification of Carthamus achenes

Archaeobotanical finds of safflower when charred are poorly preserved because of their high oil content, making it difficult to determine in many cases beyond the genus level. The criteria for determination of Carthamus, as well as those for distinguishing wild forms from the cultivated C. tinctorius, are rarely given in the corresponding publications, making comparisons difficult. The varying quality of preservation of $C$. tinctorius achenes is well illustrated by a comparison of charred and desiccated assemblages in archaeological sites (see Van der Veen 2007).

The typically white achenes of $C$. tinctorius are smooth and four-sided with differently pronounced ribs and a thick pericarp, 6-9 mm in length (Hanelt 1963). Examples in the archaeobotanical record point to the variability of the achene morphology of safflower (Kroll 1990; McCorriston 1998; Van Zeist and Waterbolk-Van Rooijen 1992). Besides typically smooth, obovoid forms, achenes also occur with a more-or-less pronounced "collar" and ribs. Examples of these can be seen in the finds from Tell Karanovo (Fig. 1a, b). The much smaller achenes of C. lanatus and $C$. dentatus, which are compact and triangular in lateral view compared to those of $C$. tinctorius, can be easily distinguished when the samples are well preserved. An example from Tell Kapitan Dimitrievo is given in Fig. 1c. The distinction of $C$. persicus and C. oxyacanthus from $C$. tinctorius is similarly straightforward. Both wild species have small achenes of $3-5.5 \mathrm{~mm}$ according to Dittrich (1968), but $C$. persicus has a shape similar to that of $C$. tinctorius, with a riffled surface near the collar, whereas $C$. oxyacanthus is obovoid. Examples of the shapes of the achenes of the most common Carthamus species in the area under consideration are given in Fig. 2. For producing the images, the morphological descriptions and studies of Hanelt (1961) and Dittrich (1968) were used as well as modern reference material from the collections of the Center for Archaeological Sciences of the K. U. Leuven and the Herbarium of the National Botanic Garden of Belgium.

Generating distribution maps from archaeobotanical databases

The archaeobotanical data referred to in this paper is presented in Table 1 and in the distribution maps (Figs. 3, 4; a complete reference list and an extended table of oil-crop finds is presented in ESM 1 and 2). The distribution maps were created with PanMap Software and with the GIS software ArcMap 9, applied to the Archaeobotanical database of Eastern Mediterranean and Near Eastern sites (Riehl and Kümmel 2005). Methodological problems relating to the interpretation of archaeobotanical distribution maps include both ambiguous chronology and inexact morphological identification of the species, which gives an uncertain representation of the data. There is regional variation in the availability of archaeobotanical data, either because of differences in settlement density per land unit, or because of differences in the amount of research invested in a specific area. For the whole area of the Near East, the data reflect both

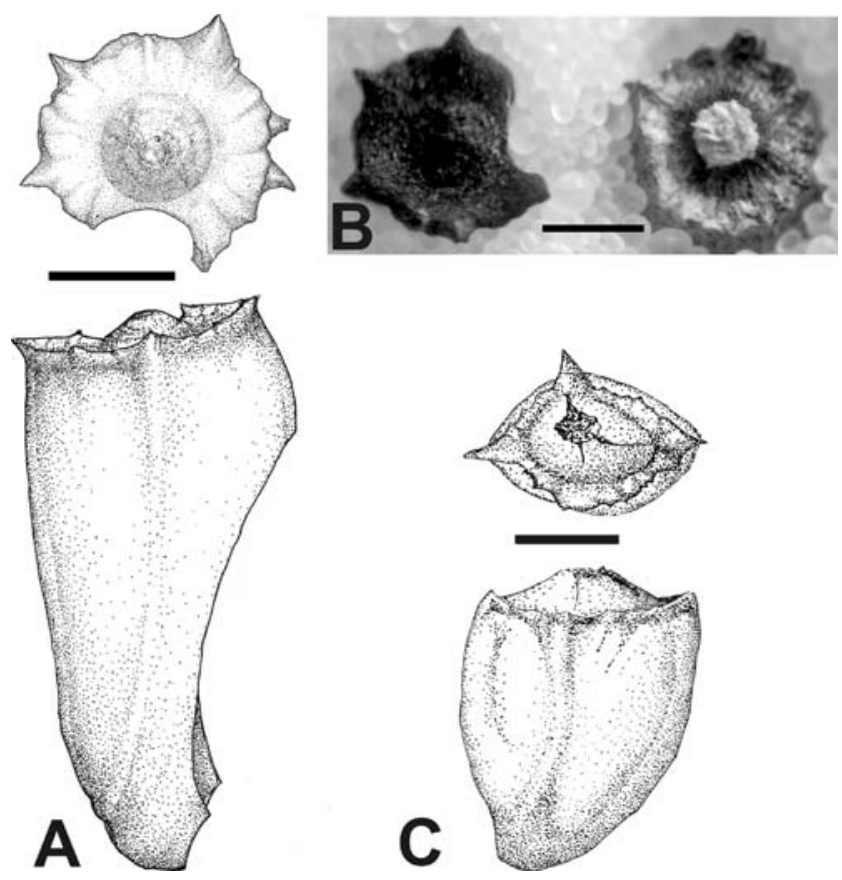

Fig. 1 Examples of archaeobotanical records of Carthamus cf. tinctorius from the early Bronze Age of Tell Karanovo: a fruit in two views, b charred specimen (left) compared to recent (right) fruit from reference collection. Carthamus lanatus from the early Neolithic of Tell Kapitan Dimitrievo, c fruit in two views. Scale $1 \mathrm{~mm}$ 
Fig. 2 Examples of the shape of typical modern specimens of a Carthamus tinctorius,

b $C$. persicus, c $C$. oxyacanthus, d C. lanatus, e C. dentatus. Scale $5 \mathrm{~mm}$
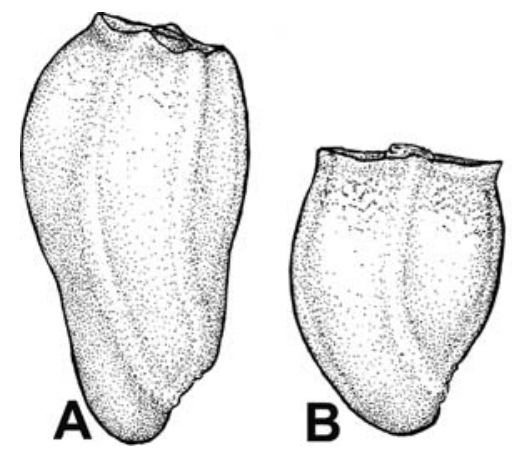
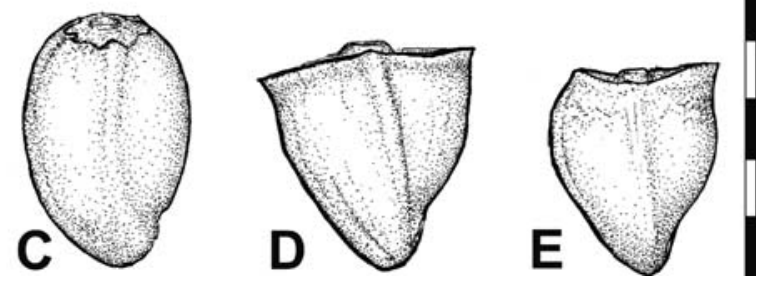

the state of research and the actual settlement patterns. However, generally a large number of sites with archaeobotanical data enable the recognition of patterns at a regional level. The large data sets available for this area as provided by the database have the potential to show general patterns and to separate out atypical data, but only further investigation can verify these patterns.

\section{Results}

The earliest archaeobotanical evidence of Carthamus sp. comes from the middle PPNB (c. 7500 в.с.) in Syria. In Europe, its first archaeobotanical finds are from the Neolithic from c. 5800 в.c. (Table 1, ESM 1).

Only from the early Bronze Age onwards (c. 3400 в.с.) does the genus occur more frequently and in larger numbers in Syria (Fig. 4a). The first secure identifications to the species level (C. tinctorius) are from this period (Table 1). The regional pattern of Carthamus in the Near East, which is related to the gradient of precipitation, deserves special attention. For the early Bronze Age, safflower was dominant in the area of the Levant and upper Mesopotamia between the modern 200 and $400 \mathrm{~mm}$ isohyets (Fig. 4a), while flax is mostly restricted to areas in the north and the Levantine coast, with higher modern mean annual precipitation (MAP).

The Bronze Age occurrence of safflower outside the Near East suggests that this plant was introduced into areas such as modern Hungary (Gyulai 1993), Serbia (Kroll 1990) and Bulgaria. The earliest safflower finds originate from the last third of the early Bronze Age in the eastern part of the Thracian plain, at Tell Karanovo at about 2800-2600 cal B.C., according to radiocarbon dates for Bulgarian prehistory of (Görsdorf and Bojadziev 1996). The plain has a natural geographical connection with the Mediterranean area through the river Maritza. The dry, hot summers in this area are advantageous for the cultivation of wheat and some Mediterranean crops. Special attention should be given to the finds of $C$. cf. tinctorius from a large early Bronze Age apse house at
Tell Karanovo. The state of preservation of the material, the high variability of Carthamus tinctorius fruits and the potential presence of $C$. lanatus (considered as growing naturally or as a weed in the area) do not allow a definite identification of the cultivated species. The highly fragmented finds of Carthamus fruits (ca. 28 specimens) were found in most cases stuck together with remains of Asteraceae inflorescences and other indeterminate charred material (Marinova 2004). The finds of remains of Asteraceae inflorescences together with the Carthamus fruits may be seen as evidence for the use of safflower as a dye-plant in the region, as discussed by Van Zeist and Waterbolk-Van Rooijen (1992) for the finds in northern Syria. On the other hand, some traditional techniques for oil extraction including crushing and low temperature heating of the safflower fruits (see Knowles 1967) can probably also produce residues similar to the observed remains in Tell Karanovo.

During the Iron Age and the Roman and Byzantine periods, most of the evidence of Carthamus comes from Egypt (Table 1, Fig. 3 and corresponding citations). An exception is finds of Carthamus from the 1st to 2nd centuries AD from Switzerland (Vandorpe 2006).

\section{Discussion}

In the discussion of the use of Carthamus in ancient times, multiple uses of crop plants are an important aspect. Use of both the dye and the oil has been described by Langethal in 1845 for central Europe (cited in Körber-Grohne 1987). In this case the flowers were cut out of the flower head, while the seeds were harvested later. Although there is no detailed description of safflower harvesting methods in ancient Near Eastern texts, multiple uses in antiquity should not be excluded. Diverse use of safflower in the past is supported by the fact that multifunctionality was a general principle in ancient societies, as for example the use of a stone artefact for different purposes in huntergatherer groups or the use of barley as a staple food, for beer brewing, or for straw for mudbrick production, as well 
Table 1 Sites with Carthamus finds considered in this paper

\begin{tabular}{|c|c|c|c|c|c|c|c|}
\hline \multirow[t]{2}{*}{ No } & \multirow[t]{2}{*}{ Site name } & \multirow[t]{2}{*}{ Location } & \multirow[t]{2}{*}{ Identification } & \multicolumn{2}{|l|}{ Number } & \multirow[t]{2}{*}{ Period } & \multirow[t]{2}{*}{ References } \\
\hline & & & & Achenes & $\begin{array}{l}\text { Total } \\
\text { seeds/fruits }\end{array}$ & & \\
\hline \multicolumn{8}{|c|}{ Neolithic/Chalcolithic } \\
\hline 1 & Abu Hureyra & Syria & Carthamus sp. & 1 & - & PPNB & Hillman et al. (1989) \\
\hline 2 & Tell Aswad & Syria & Carthamus sp. & 1 & - & PPNB & $\begin{array}{l}\text { Van Zeist and Bakker- } \\
\text { Heeres (1982) }\end{array}$ \\
\hline 3 & Wadi Jilat 7 & Jordan & Carthamus sp. & 6 & - & PPNB & Colledge (2001) \\
\hline 4 & Mylouthkia & Cyprus & Carthamus sp. & 1 & 8,856 & Early Chalcolithic & Colledge (2003a) \\
\hline 5 & $\begin{array}{l}\text { Tell Kapitan } \\
\text { Dimitrievo }\end{array}$ & Bulgaria & $\begin{array}{l}\text { Carthamus cf. } \\
\text { lanatus }\end{array}$ & 2 & 742 & Early Neolithic & Marinova (in press) \\
\hline 6 & "La Marmotta" & Italy & Carthamus lanatus & 325 & 18,000 & Neolithic & Rottoli 2000-2001 \\
\hline 7 & Kumtepe & Turkey & Carthamus sp. & 3 & 25,712 & Chalcolithic & Riehl (1999a) \\
\hline \multicolumn{8}{|c|}{ Bronze Age } \\
\hline 8 & Emar & Syria & Carthamus sp. & 1 & 20,164 & Early Bronze Age & Riehl (1999b) \\
\hline 9 & Hajji Ibrahim & Syria & $\begin{array}{l}\text { Carthamus } \\
\text { tinctorius }\end{array}$ & 1 & 4,960 & Early Bronze Age & Miller (1997) \\
\hline 10 & Hirbet ez-Zeraqon & Jordan & Carthamus sp. & 1 & 122,637 & Early Bronze Age & Riehl (2004) \\
\hline 11 & Qatna & Syria & $\begin{array}{l}\text { Carthamus } \\
\text { tinctorius }\end{array}$ & 1 & - & Early Bronze Age & Riehl (unpublished) \\
\hline 12 & Tell al-Raqa'i & Syria & $\begin{array}{l}\text { Carthamus } \\
\text { tinctorius }\end{array}$ & 14 & 27,708 & Early Bronze Age & $\begin{array}{l}\text { Van Zeist }(1999 / 2000, \\
\text { 2001) }\end{array}$ \\
\hline 13 & Tell al-Rawda & Syria & $\begin{array}{l}\text { Carthamus } \\
\text { tinctorius }\end{array}$ & 29 & 7,617 & Early Bronze Age & Herveux (2004) \\
\hline 14 & Tell Atij & Syria & $\begin{array}{l}\text { Carthamus } \\
\text { tinctorius }\end{array}$ & 8 & 8,174 & Early Bronze Age & McCorriston (1995) \\
\hline 15 & Tell Atij & Syria & $\begin{array}{l}\text { cf. Carthamus } \\
\text { tenuis }\end{array}$ & 2 & 8,174 & Early Bronze Age & McCorriston (1995) \\
\hline 16 & Tell Bderi & Syria & $\begin{array}{l}\text { Carthamus } \\
\text { tinctorius }\end{array}$ & 1 & 102,600 & Early Bronze Age & Engel (1993) \\
\hline 17 & $\begin{array}{l}\text { Tell Hammam et- } \\
\text { Turkman }\end{array}$ & Syria & Carthamus sp. & 2 & 615 & Early Bronze Age & Van Zeist et al. (1988) \\
\hline 18 & Tell Selenkahiye & Syria & $\begin{array}{l}\text { Carthamus } \\
\text { tinctorius }\end{array}$ & 27 & 81,216 & Early Bronze Age & $\begin{array}{l}\text { Van Zeist and Bakker- } \\
\text { Heeres (1985) }\end{array}$ \\
\hline 19 & Tell Shiukh Fawqani & Syria & Carthamus sp. & 12 & 22,548 & Early Bronze Age & Pessin (2004) \\
\hline 20 & Umm el-Marra & Syria & $\begin{array}{l}\text { Carthamus } \\
\text { tinctorius }\end{array}$ & 10 & 3,770 & Early Bronze Age & Miller (2000) \\
\hline 21 & Tell Brak & Syria & $\begin{array}{l}\text { Carthamus } \\
\text { tinctorius }\end{array}$ & 17 & 372984 & $\begin{array}{l}\text { Early to Middle } \\
\text { Bronze Age }\end{array}$ & $\begin{array}{l}\text { Charles (2001); } \\
\text { Colledge (2003b) }\end{array}$ \\
\hline 22 & Tell Brak & Syria & Carthamus sp. & 47 & 138,060 & Middle Bronze Age & $\begin{array}{l}\text { Charles and Bogaard } \\
\text { (2001); Colledge } \\
\text { (2003b) }\end{array}$ \\
\hline 23 & Tell Mozan & Syria & $\begin{array}{l}\text { Carthamus } \\
\quad \text { tinctorius }\end{array}$ & 1 & 11,118 & Middle Bronze Age & Riehl (2000) \\
\hline 24 & Umm el-Marra & Syria & $\begin{array}{l}\text { Carthamus } \\
\text { tinctorius }\end{array}$ & 2 & 4,592 & Middle Bronze Age & Miller (2000) \\
\hline 25 & Tell Karanovo & Bulgaria & $\begin{array}{c}\text { Carthamus cf. } \\
\text { tinctorius }\end{array}$ & 28 & 1,722 & Early Bronze Age & Marinova (2004) \\
\hline 26 & Feudvar & Serbia & $\begin{array}{l}\text { Carthamus } \\
\text { tinctorius }\end{array}$ & 1 & ca. 250,000 & Middle Bronze Age & Kroll (1990, 1998) \\
\hline 27 & Turkeve-Terehalom & Hungary & $\begin{array}{l}\text { Carthamus } \\
\text { tinctorius }\end{array}$ & 1,245 & 37,989 & Late Bronze Age & Gyulai (1993) \\
\hline 28 & Ulu Burun & Turkey & Carthamus lanatus & + & - & Late Bronze Age & Haldane $(1991 \mathrm{a}, \mathrm{b})$ \\
\hline 29 & Hala Sultan Tekke & Cyprus & Carthamus lanatus & 1 & 4,830 & Late Bronze Age & Hjelmqvist (1979) \\
\hline
\end{tabular}


Table 1 continued

\begin{tabular}{|c|c|c|c|c|c|c|c|}
\hline \multirow[t]{2}{*}{ No } & \multirow[t]{2}{*}{ Site name } & \multirow[t]{2}{*}{ Location } & \multirow[t]{2}{*}{ Identification } & \multicolumn{2}{|l|}{ Number } & \multirow[t]{2}{*}{ Period } & \multirow[t]{2}{*}{ References } \\
\hline & & & & Achenes & $\begin{array}{l}\text { Total } \\
\text { seeds/fruits }\end{array}$ & & \\
\hline 30 & Tutankhamun tomb & Egypt & $\begin{array}{l}\text { Carthamus } \\
\text { tinctorius }\end{array}$ & + & - & Late Bronze Age & $\begin{array}{l}\text { Germer (1989); Hepper } \\
\quad \text { (1990) }\end{array}$ \\
\hline 31 & Rukeis & Jordan & Carthamus type & 27 & 466 & Bronze Age & Willcox (internet) \\
\hline \multicolumn{8}{|c|}{ Iron Age and later } \\
\hline 32 & Tell Shiukh Fawqani & Syria & Carthamus sp. & 9 & 22,504 & Early Iron Age & Pessin (2004) \\
\hline 33 & Tell Shiukh Fawqani & Syria & Carthamus sp. & 3 & - & Late Iron Age & $\begin{array}{l}\text { Pessin and Klesly (in } \\
\text { press) }\end{array}$ \\
\hline 34 & Larsa & Iraq & Carthamus sp. & 26 & 3,414 & Hellenistic period & Neef $(1989 b)$ \\
\hline 35 & Fayum & Egypt & $\begin{array}{l}\text { Carthamus } \\
\text { tinctorius }\end{array}$ & - & - & $\begin{array}{l}\text { Hellenistic/Roman } \\
\text { period }\end{array}$ & $\begin{array}{l}\text { Caton-Thompson and } \\
\text { Gardener (1934) }\end{array}$ \\
\hline 36 & Abi'or cave & Israel & Carthamus nitidus & 1 & 828 & Roman period & Kislev (1992) \\
\hline 37 & Tell Hadidi & Syria & $\begin{array}{l}\text { Carthamus } \\
\text { tinctorius }\end{array}$ & 1 & 1,278 & Roman period & $\begin{array}{l}\text { Van Zeist and Van } \\
\text { Rooijen (1985) }\end{array}$ \\
\hline 38 & Mons Claudianus & Egypt & $\begin{array}{l}\text { Carthamus } \\
\text { tinctorius }\end{array}$ & 102 & 16,109 & Roman period & Van der Veen (2001) \\
\hline 39 & Mons Porphyrites & Egypt & $\begin{array}{l}\text { Carthamus } \\
\text { tinctorius }\end{array}$ & 547 & 30,812 & Roman period & $\begin{array}{l}\text { Van der Veen and } \\
\text { Tabinor (2007) }\end{array}$ \\
\hline 40 & Berenike & Egypt & $\begin{array}{l}\text { Carthamus } \\
\text { tinctorius }\end{array}$ & + & - & Roman period & Cappers (2006) \\
\hline 41 & $\begin{array}{l}\text { Oedenburg/ } \\
\text { Biesheim- } \\
\text { Kunheim }\end{array}$ & Switzerland & $\begin{array}{l}\text { Carthamus } \\
\text { tinctorius }\end{array}$ & + & - & Roman period & Vandorpe (2005) \\
\hline 42 & Kom el-Nana & Egypt & $\begin{array}{l}\text { Carthamus } \\
\text { tinctorius }\end{array}$ & 451 & 29,969 & Late Antique & Smith (2003) \\
\hline 43 & Deyr al-Barsha & Egypt & $\begin{array}{l}\text { Carthamus } \\
\text { tinctorius }\end{array}$ & 3 & - & Late Antique & Marinova unpublished \\
\hline 44 & Kaman-Kalehöyük & Turkey & Carthamus sp. & 2 & 295,074 & $\begin{array}{l}\text { Ottoman period and } \\
\text { Medieval }\end{array}$ & $\begin{array}{l}\text { Nesbitt }(1993,1995) ; \\
\text { Fairbairn }(2002, \\
\text { 2003, 2004); } \\
\text { Kennedy }(2000)\end{array}$ \\
\hline
\end{tabular}

as the use of the grain as a cash crop in the Bronze Age Near East. Further evidence is the high range of variation in modern Carthamus (Dajue and Mündel 1996).

In the following, we discuss the archaeobotanical distribution evidence of the genus Carthamus as reflected by archaeobotanical and other sources of information and in relation to cultural developments.

The use of Carthamus species: the archaeobotanical and written evidence

The Neolithic and Chalcolithic archaeobotanical finds of the genus suggest that the plant was an early crop in the study area. The numerous $C$. lanatus finds from $\mathrm{La}$ Marmotta, Italy (Table 1) are an indication of possible collection and use of its fruits.

Finds of Carthamus in Near Eastern Bronze Age and eastern European archaeological sites are usually interpreted as being related to dyeing, because of widely known textual evidence of the second millennium B.C. from Egypt and Crete (cf. Zohary and Hopf 2000). In India, ancient texts document the use of two pigments from the plant, safflower yellow and safflower carmine, at least since the Vedic period (ca. 1500600 в.C.; Rau 1970). Archaeological safflower found in Rajasthan dates to around 2000 B.C. (Pokharia 2008). During the Iron Age and the Roman period, safflower became more restricted in its distribution and was cultivated mainly in Egypt (Table 1). From this region and these periods there is clear evidence that the plant was cultivated for oil extraction in considerable amounts and that the seeds were traded widely (Sandy 1989). A Ptolemaic (325-30 B.c.) papyrus mentions safflower cultivation covering up to $18 \%$ of the land used for farming and that it was only outnumbered by wheat (Monson 2007). Körber-Grohne (1987) also suggested that the oil of $C$. tinctorius was part of the oil monopoly during this time. 
Fig. 3 Location of the sites with Carthamus finds considered in the publication. The numbers of the sites are given in Table 1, references in ESM; sites with identifications of Carthamus tinctorius are marked in grey

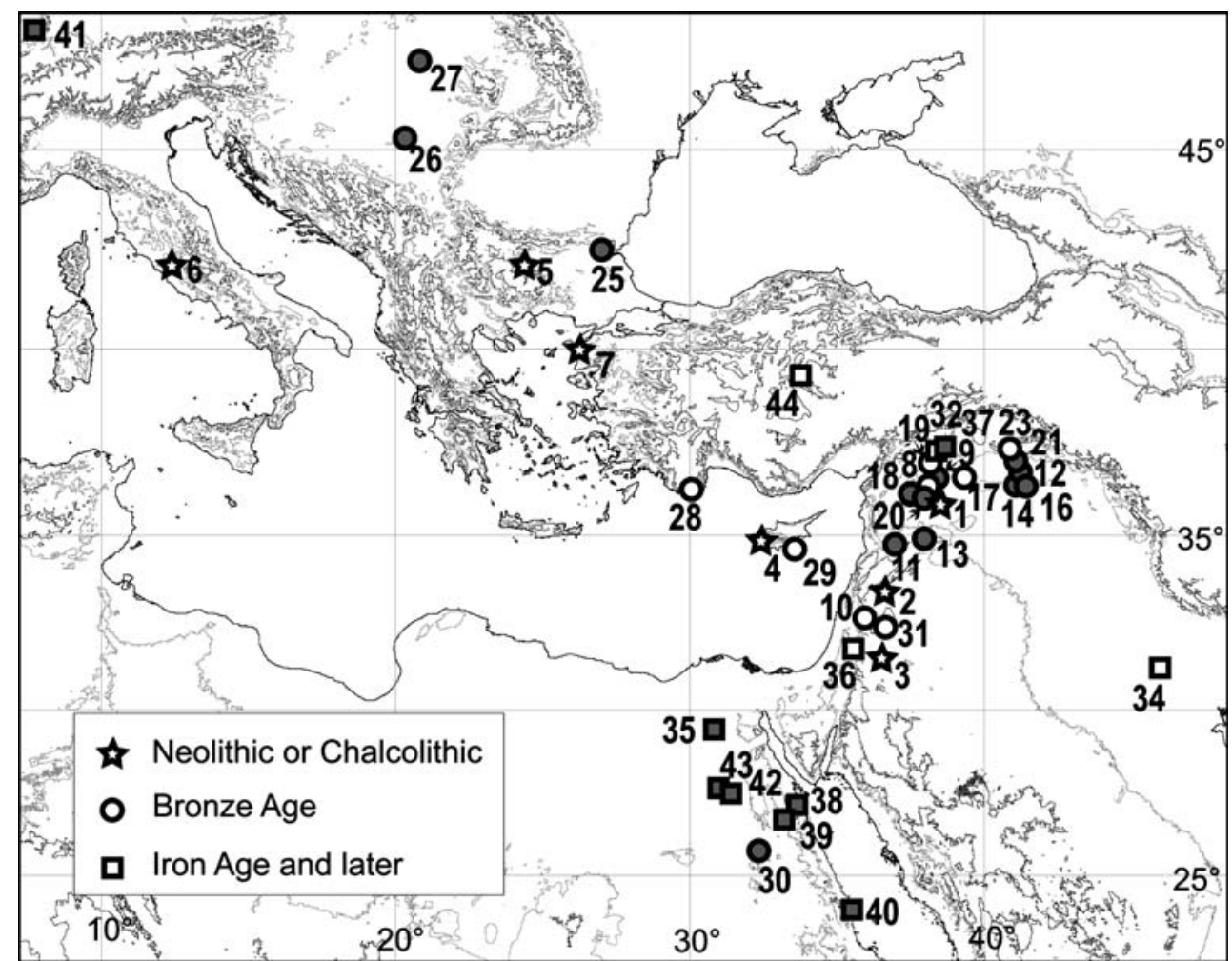

This geographical restriction may be explained by the increased use of other oil crops such as flax, thus reducing demand for safflower. In the Levant, animal sources for red pigment became more and more important in the Roman and Byzantine periods (Koren 2005). In this connection it should be noted that the fewer finds of safflower in the Roman and later periods in the Near East could also reflect less archaeobotanical information compared to Neolithic to Bronze Age periods (see the database: http://www. cuminum.de/archaeobotany).

Besides textual information, biochemical methods can also be taken into consideration for investigating the use of Carthamus oils. Studies on balm used for mummification showed that unsaturated oils of botanical origin were in many cases the key ingredients. However, it is impossible to assign a precise plant origin to the identified fatty acids, owing to the degradation of the major unsaturated components (Buckley and Evershed 2001). This also holds for the fatty acid profile of safflower oil, which cannot be clearly differentiated, making the proof of its presence in pottery impossible (Buckley and Evershed 2001).

Archaeobotanical distribution patterns in the Near East

Many references concentrate on the value of safflower as a dye, and consider oil production to be a more recent development that was not of economic importance in the past (Zohary and Hopf 2000). The hope that the consideration of the archaeological contexts of the safflower finds would help to clarify their use is in most cases not sound, for various reasons. While it is generally questionable whether conclusions drawn from classification of archaeobotanical remains according to archaeological contexts are meaningful, there is a considerable lack of context information in most archaeobotanical reports. For $14 \%$ of the Syrian finds no contextual details are available, $40 \%$ derive from sample contexts described as occupational deposits, $12 \%$ are from ashy layers and $8 \%$ from ovens, while the remaining $26 \%$ come from floors, pits and middens.

Bearing in mind the textual evidence and analysing archaeobotanical distribution of Carthamus in relation to other oil crops, this assumption should be reconsidered.

The distribution patterns of various oil plants in the Near East are similar for safflower and flax finds, particularly for the early Bronze Age (Fig. 4). This may be in some way related to their different ecological preferences. In the area where $C$. tinctorius is distributed, hardly any other oil crops are found, suggesting that it was indeed used as an oil plant. In contrast to flax, safflower is a crop well-adapted to arid conditions, with a strong tolerance of drought and salinity (Kalane et al. 1992; Quiroga et al. 2001; El Nakhlawy and El Fawal 1989). Increased salinity, which can cause a loss in yield of flax of up to $50 \%$, has no effect on safflower. The salt tolerance of safflower is only exceeded by that of barley, which has an ancient distribution pattern in central Syria in the area between 200 and 

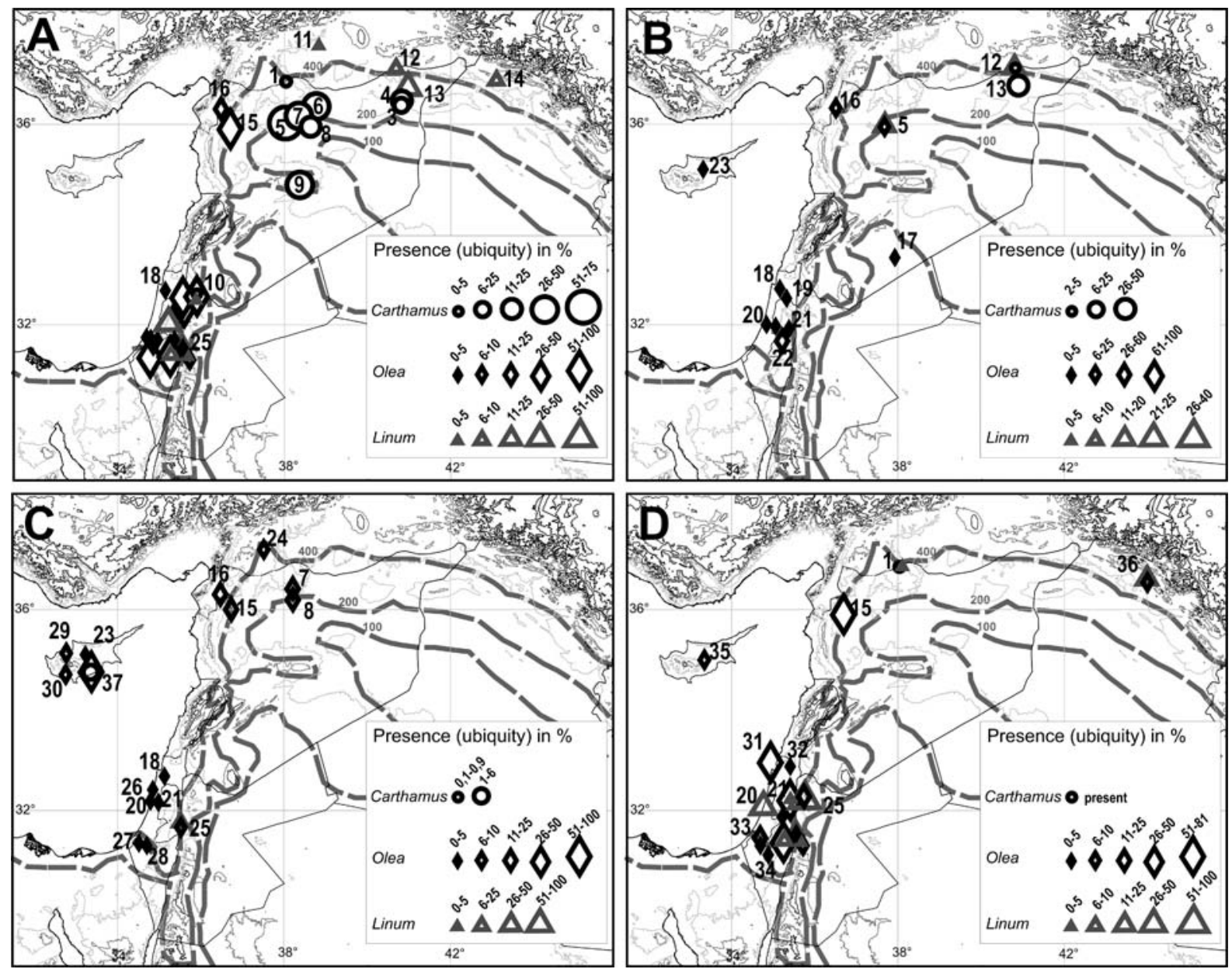

Fig. 4 Presence and distribution of Carthamus, Olea and Linum in the Levant and upper Mesopotamia during: a the early Bronze Age (c. 3400-2000 в.с.), b the Middle Bronze Age (c. 2000-1600 в.c.), c the late Bronze Age (c. $1600-1200$ B.c.), and d the Iron Age (c. 1200-600 B.c.). Isohyets show modern MAP. 1 Tell Shiukh Fawqani, 2 Tell Hammam et-Turkman, 3 Tell Bderi, 4 Tell al-Raqa'i and Tell Atij, 5 Umm el-Marra, 6 Hajji Ibrahim and Tell es-Sweyhat, 7 Tell Selenkahiye, 8 Emar, 9 Tell al-Rawda, 10 Hirbet ez-Zeraqon,

$300 \mathrm{~mm}$ of mean annual precipitation. The general sparseness of flax and olive in central Syria suggests that safflower was also used as an oil crop at least in this area.

The reduction of middle Bronze Age sites in northern Mesopotamia to the area above the modern $200 \mathrm{~mm}$ isohyets in relation to the 4,200 BP climatic event complicates the recognition of a clear distribution pattern of crops (Staubwasser and Weiss 2006; Riehl and Bryson 2007; Riehl et al. 2008; Riehl 2007). Single finds of Carthamus and Linum sp. in the upper Khabur area during the middle Bronze Age cannot prove the significant cultivation of both crop plants.

The "multipurpose" flax, which has been mainly reported for its use in linen production, seems to have been replaced in the market by wool during this period (Riehl 2008). During the following late Bronze Age and Iron Age, safflower is further reduced in the area of the Fertile Crescent,

11 Kurban Höyük, 12 Tell Mozan, 13 Tell Brak, 14 Tell Karrana, 15 Tell Afis, 16 Tell Atchana and Tell Kurdu, 17 Umbashi, 18 Tell Qashish and Tell Yoqneam, 19 Tell Taannach, 20 Tell Gerisa and Tell Qasile, 21 Tell Aphek, 22 City of David and Manahat, 23 MarkiAlonia, 24 Tilbeshar, 25 Deir' Alla, 26 Tell Michal, 27 Tell Sera, 28 Tell Halif, 29 Apliki, 30 Ayios Dhemetrios, 31 Tell Qiri, 32 'Afula, 33 Lachish, 34 Tell 'Ira, 35 Dhali Agridhi and Idalion, 36 Nimrud, 37 Hala Sultan Teke

suggesting that the main period of Carthamus cultivation in the Near East was indeed during the early Bronze Age.

To reduce the described changes in the transition from the early to the middle Bronze Age to a common denominator, increasing aridity in the area drove people to switch from low yielding crops such as safflower for dye and oil production, as well as from drought-intolerant crops like flax for linen and oil production to high yielding crops like olive and drought-independent animal resources like sheep and goat for wool and fat or Murex species for red dye (Riehl 2008).

Archaeobotanical distribution patterns of Carthamus tinctorius in eastern Europe and adjacent regions

The evidence of about four potentially oil-yielding species in late Bronze Age sites in northern Greece suggests an 
increasing importance of oil production during this period. Jones and Valamoti (2005) propose that in areas where olive cannot be reliably grown, attempts were made to find a locally cultivable source of oil during the Bronze Age. The early Bronze Age cultivation of Carthamus in central and northern Syria may have been a similar attempt to select the most suitable oil crop for a specific environment.

In south-eastern Europe, Carthamus cultivation first appeared during the Bronze Age (Table 1). Although in the agronomic literature the Aegean region and eastern Europe are usually not included in the area of its ancient cultivation, the mention of the plant in Linear B texts from Crete (Sarpaki 2001) suggests that the extent of ancient cultivation areas of safflower (Hanelt 1961; Smith 1996) needs to be revised. During this period various crops had a potential use as an oil source in the south-eastern European settlements. Amongst these, the use of Linum, Camelina sativa (Kroll 1990; Riehl 1999; Marinova 2003) and Lallemantia (Jones and Valamoti 2005) as oil crops is very likely.

The occurrence of a crop adapted to arid areas, like Carthamus, in Bronze Age Europe may be a sign of farreaching cultural and economic exchange. It coincides with the occurrence of similar crops that appear during the Bronze Age in the region. Long-distance contacts with communities to the east have been suggested, for example for Lallemantia (Jones and Valamoti 2005).

An interesting aspect of Carthamus distribution is its virtual absence from Turkey, which would have supposedly functioned as a bridge for the regional distribution of the crop between the Near East and eastern Europe.

Carthamus seeds were found at medieval and Ottoman Kaman Kalehöyük with two records (Kennedy 2000), as well as in the Aegean Troad at the Chalcolithic site of Kumtepe with only three finds (Riehl 1999). Besides the relatively low density of excavated archaeological sites in Turkey, the lack of safflower fruits in this region raises questions about how safflower itself, or the knowledge of its use, was distributed. Another possible explanation of this absence could be of economic character, for if safflower was traded by sea there would be no need to go through Anatolia. Overall, the lack of safflower in Turkey suggests an exclusive importance of this plant in the Mediterranean region.

\section{Conclusions}

The archaeobotanical record of Carthamus dates back to the PPNB (c. 8800-6500 в.с.). The occurrence of the cultivated species in large numbers in central Syria as early as 3000 в.с. and its generally later appearance in adjacent regions of the Near East including northwest India suggest the diffusion of Carthamus tinctorius out of central Syria into adjacent regions. The distribution area of the early cultivated species corresponds to that of wild $C$. persicus.

The occurrence of $C$. tinctorius outside its original area of cultivation in south-eastern Europe as early as 2800 2600 cal B.c. reflects the wide-reaching cultural contacts and interactions during the Bronze Age between the eastern Mediterranean and adjacent regions. The regional difference in the presence of either flax or safflower at Near Eastern early Bronze Age sites supports the idea of agricultural provinces, which seem to be related to environmental conditions such as available soil moisture and suggest the use of safflower during the early Bronze Age not only as a dye but also as an oil crop.

Acknowledgments The database of Near Eastern archaeobotanical finds was authoritatively financed by the German Research Council to which we owe gratitude. We thank M. Van der Veen and anonymous referees who essentially improved the paper. We are grateful to $\mathrm{H}$. E. Wright for improving the English of the text.

\section{References}

Buckley S, Evershed R (2001) Organic chemistry of embalming agents in Pharaonic and Graeco-Roman mummies. Nature 413:837-841

Chapman M, Bruke J (2007) DNA sequence diversity and the origin of cultivated safflower (Carthamus tinctorius L.; Asteraceae). BMC Plant Biol 7:60. doi:10.1186/1471-2229-7-60

Dajue L, Mündel H-H (1996) Safflower Carthamus tinctorius L. Institute of Plant Genetics and Crop Plant Research, Gatersleben/ International Plant Genetic Resources Institute, Rome

Dittrich M (1968) Morphologische Untersuchungen an den Früchten der Subtribus Cardueae-Centaureinae (Compositae). Willdenowia 5:67-107

El Nakhlawy FS, El Fawal MA (1989) Tolerance of five oil crops to salinity and temperature stresses during germination. Acta Agron Hung 38:59-66

Görsdorf J, Bojadziev J (1996) Zur absoluten Chronologie der bulgarischen Urgeschichte. Berliner C14 Datierungen von bulgarischen archäologischen Fundplätzen. Eurasia Antiqua 2:105-173

Gyulai F (1993) Environment and agriculture in Bronze Age Hungary (Archaeolingua Series Minor 4). Hungarian Academy of Sciences, Budapest, pp 7-59

Hanelt P (1961) Zur Kenntnis von Carthamus tinctorius L. Kulturpflanze 9:114-145

Hanelt P (1963) Monographische Uebersicht der Gattung Carthamus L. Feddes Repert 67:41-180

Jones G, Valamoti S (2005) Lallemantia, an imported or introduced oil plant in Bronze Age northern Greece. Veget Hist Archaeobot 14:571-577

Kalane RL, Dhopte AM, Kharkar PT, Deshmukh SD (1992) Studies on evapotranspiration by winter crops from shallow water table. Ann Plant Physiol 6:145-148

Kennedy A (2000) Ottoman plant remains from Kaman-Kalehöyük. Anatolian Archaeol Stud 9:147-165

Knowles PF (1967) Processing seeds for oil in towns and villages of Turkey, India and Egypt. Econ Bot 21:156-162

Knowles PF, Ashri A (1995) Safflower: Carthamus tinctorius (Compositae). In: Smartt J, Simmonds NW (eds) Evolution of crop plants, 2nd edn. Longman, Harlow, pp 47-50 
Körber-Grohne U (1987) Nutzpflanzen in Deutschland. Theiss, Stuttgart

Koren ZC (2005) The first optimal all-Murex all-natural purple dyeing in the eastern Mediterranean in a millennium and a half. Dyes Hist Archaeol 20:136-149

Kroll H (1990) Ein Fruchtfund von Carthamus tinctorius belegt diese Färbepflanze für die Bronzezeit Jugoslaviens. Arch Korr 20:41-46

Kupcov AI (1932) Geografskaja variabilnost Carthamus tinctorius L. [The geographical variability of Carthamus tinctorius L., in Russian]. Bull Appl Bot Genet Plant Breed 9:99-181

Marinova E (2003) Paleoethnobotanical study of Early Bronze II in the Upper Stryama Valley (Dubene-Sarovka IIB) 1. In: Nikolova L (ed) Early symbolic systems for communication in southeast Europe (BAR International Series 1139, vol 2). Archaeo Press, Oxford, pp 499-504

Marinova E (2004) Archäobotanische Ergebnisse aus der Bronzezeit von Tell Karanovo und ihr regionaler Kontext. Diomedes 3:53-58

McCorriston J (1998) Syrian origins of safflower production: new discoveries in the agrarian prehistory of the Habur Basin. In: Damania AB, Valkoun J, Willcox G, Qualset CO (eds) The origins of agriculture and crop domestication. ICARDA, Syria, pp 39-50

Monson A (2007) An early ptolemaic land survey in Demotic: P. Cair II:31073

Pokharia AK (2008) Record of macrobotanical remains from the Aravalli Hill, Ojiyana, Rajasthan: evidence for agriculture-based subsistence economy. Curr Sci 94:612-622

Quiroga AR, Díaz-Zorita M, Buschiazzo DE (2001) Safflower productivity as related to soil water storage and management practices in semiarid regions. Commun Soil Sci Plant Anal 32:2851-2862

Rau W (1970) Weben und Flechten im Vedischen Indien. Abhandlungen der Geistes- und sozialwissenschaftlichen Klasse der Akademie der Wissenschaften und der Literatur, Mainz, Jahrg. I970, Nr. II, Wiesbaden

Riehl S (1999) Bronze Age environment and economy in the Troad: the archaeobotany of Kumtepe and Troy. Mo Vince Verlag, Tübingen

Riehl S (2007) Archaeobotanical evidence for the interrelationship of agricultural decision-making and climate change in the ancient Near East. Quatern Internat. doi:10.1016/j.quaint.2007.08.005

Riehl S (2008) Climate and agriculture in the ancient Near East: a synthesis of the archaeobotanical and stable carbon isotope evidence. Veget Hist Archaeobot 17(Suppl 1):43-51

Riehl S, Bryson RA (2007) Variability in human adaptation to changing environmental conditions in Upper Mesopotamia during the Early to Middle Bronze Age transition. In: Marro C, Kuzucuoglu C (eds) Sociétés humaines et changement climatique à la fin du troisième millénaire: une crise a-t-elle eu lieu en Haute-Mésopotamie? Varia Anatolica. de Boccard, Paris, pp 523-548

Riehl S, Kümmel C (2005) Archaeobotanical database of Eastern Mediterranean and Near Eastern sites. http://www.cuminum. de/archaeobotany

Riehl S, Bryson RA, Pustovoytov K (2008) Changing growing conditions for crops during the Near Eastern Bronze Age (3000 1200 в.c.): the stable carbon isotope evidence. J Archaeol Sci 35:1011-1022

Sandy DB (1989) The production and use of vegetable oils in Ptolemaic Egypt. Scholars Press, Atlanta

Sarpaki A (2001) Condiments, perfume and dye plants in Linear B: a look at the textual and archaeobotanical evidence. In: Michailidou A (ed) Manufacture and measurement: counting, measuring and recording craft items in early Aegean societies. Research Center for Greek and Roman Antiquity, National Hellenic Research Foundation, Athens, pp 195-265

Smith J (1996) Safflower. AOCS Press, Urbana-Champaign

Staubwasser M, Weiss H (2006) Holocene climate and cultural evolution in late prehistoric-early historic West Asia. Quat Res 66:372-387

Van der Veen M (2007) Formation processes of desiccated and charred plant remains - the identification of routine practice. J Archaeol Sci 34:968-990

Van Zeist W, Waterbolk-Van Rooijen W (1992) Two interesting floral finds from third millennium B.c. Tell Hammam etTurkman, northern Syria. Veget Hist Archaeobot 1:157-161

Vandorpe P (2006) Plant macro remains from the 1st and 2nd C A.D. in Roman Oedenburg/Biesheim-Kunheim (F). Methodological aspects and insights into local nutrition, agricultural practices, import and the natural environment. Doctoral thesis, University of Basel

Weiss EA (2000) Oilseed crops. Blackwell, Oxford

Zeven A, Zhukovsky P (1975) Dictionary of cultivated plants and their centres of diversity: excluding ornamentals, forest trees and lower plants. Centre for Agricultural Publishing and Documentation, Wageningen

Zohary D, Hopf M (2000) Domestication of plants in the Old World: the origin and spread of cultivated plants in West Asia, Europe, and the Nile Valley, 3rd edn. Oxford University Press, Oxford 